\title{
Measuring Theory Planned Behavior of Students to become Entrepreneurs (Case Study at School of Economic Pasundan Bandung, Indonesia)
}

\author{
Dedi Hadian \\ School of Economic Pasundan, Bandung, Indonesia \\ JL. Turangga No. 37 - 41, Bandung, Indonesia. 40263 \\ Email: dedi@stiepas.ac.id \\ Senen Machmud \\ School of Economic Pasundan, Bandung, Indonesia \\ JL. Turangga No. 37 - 41, Bandung, Indonesia. 40263 \\ Email: senenmachmud@stiepas.ac.id
}

\begin{abstract}
Dudung Juhana
School of Economic Pasundan, Bandung, Indonesia

JL. Turangga No. 37 - 41, Bandung, Indonesia. 40263

Email: dudung@stiepas.ac.id
\end{abstract}

Iwan Sidharta (Corresponding author)

School of Management, Informatics and Computer, Mardira Indonesia, Bandung

Jl. Soekarno-Hatta No. 211 Leuwipanjang - Jawa Barat, Indonesia

Tel 622-5230382 fax :622-5230382,Email: i_sidh@stmik-mi.ac.id

Doi:10.5296/ijhrs.v5i3.8205 URL: http://dx.doi.org/10.5296/ijhrs.v5i3.8205

\begin{abstract}
Some research indicates the importance of increasing the number of entrepreneurs for a country's economic resilience. Increased reliable entrepreneurs cannot be separated from the role of universities in preparing graduates in accordance with the competencies they must
\end{abstract}


have. Thus there is a need for a study of the factors that influence students to choose a career as a reliable entrepreneur. This study aims to determine the attitude factors, contextual factors, and gender factors that affect the intention of students to become entrepreneurs. Exploratory research methods of data analysis were using Structural Equation Modelling (SEM) and component-based Partial Least Squares (PLS). Total respondents were 269 students with the data collection technique of accidental sampling. The results showed that the attitude factors influence positively the entrepreneurial intention by $32.3 \%$, the influence of contextual factors $26.2 \%$. Moreover, the gender factors influence student's attitudes towards intentions to become entrepreneurs but do not affect the contextual factors on the intention of students to become entrepreneurs.

Keywords: Attitude factor; contextual factors; entrepreneurial intention; entrepreneurship

\section{Introduction}

Based on the 1945 Constitution to explicitly emphasize the implementation of the principle of kinship (Article 33, paragraph 1) and the implementation of a national economy which is based on democracy in economy (Article 33, paragraph 4) in this case the empowerment of Small and Medium Enterprises is integral part of national development that aims to realize a just and prosperous society. In this regard, the empowerment of entrepreneurs is required, especially for those directly related to life and increased prosperity for the development of the area around the strategic potentials possessed by SMEs (Machmud and Sidharta, 2013). The development approach is aimed foreconomic actors, particularly SMEs, to become a necessity in order to evolve into nationally economic actors havingstrong and independent structures. In line with the demands of the rapid changes, the technological advances push the new paradigm in the field of entrepreneurship, where the process of entrepreneurship is only obtained from direct experiences in the field. It transforms from a skillthatis obtained since birth, intoa discipline that can be learned and taught. The learning process of entrepreneurship discipline is conducted by universities to create a young generation that has a stock of knowledge, skills and ability to create new jobs that can absorb a lot of labor.

Unemployment rate in Indonesia in 2014 is as many as 7.2 million people in which the graduate diploma and university are 688.660 people or $9.5 \%$ of the total unemployment, while in 2013 the number of open unemployment from university and diploma amounts to 619.288 people or $8.4 \%$ of total unemployment (BPS, 2014 ). This is a matter that needs to observe and study further in order the government's program in improving the SME's sector can be achieved (Machmud dan Sidharta, 2014). There needs to be a concrete step in creating entrepreneurs. College is an academic means that can perform the role. Increasing superior human resources must also be the role of universities to prepare qualified graduates so as to produce reliable entrepreneurs. This is done in order to improve the competitiveness of the national economy in connection with the implementation of the Asian Economic Community (AEC) by the end of 2015. 
Entrepreneurship can be seen from the internal factors and external factors. According to Neffziger et al., (1994) the measurement which is widely used in entrepreneurial intention is determined by three factors, namely personality characteristic, personal and contextual traits in which these three factors are internal factors. The role of universities can encourage the creation of entrepreneurs with respect to transfering appropriate knowledge and skills (Sidharta \& Lusyana, 2014) so as to increase self-efficacy (Baum, 1994) so the novice entrepreneurs can be effective in starting their first attempt (Gorman et al., 1997). Increased entrepreneurship can be realized by universities through a process of education, values and attitudes, personal goals, creativity, dare to risk and locus of control (Gibb, 1994). Based on the study results of Bates (1995), it was found a positive effect between education and entrepreneurial intention. To predict the attitude factors towards intentions to become entrepreneurs can adopt Theory of Planned Behavior (Ajzen, 1985, 1987) which prediction is based on (1) the attitude toward the behavior, (2) subjective norms, (3) control behavior received, and (4) the intention to be an entrepreneur. Several studies have been conducted, such as Gurbuz \& Aykol (2008), Suharti \& Sirine (2011), Sidharta \& Sidh (2013) and Amos $\&$ Alex (2014) that found a significant effect of factors and contextual attitudes towards entrepreneurial intentions. The limited empirical research about the intentions of students to become entrepreneurs is one of the reasons in conducting this study.

Based on the phenomena as described above, the formulation of the problem is as follows; To what extent the effect of autonomy and authority, economic opportunity and challenge, security and work load, avoid responsibility, self realization and participation, social environment and career, perceived confidence and contextual factors that include academic support, social support and support of environment and gender factors on the intention to become entrepreneurs among students at School of Economic Pasundan Bandung, Indonesia. The purpose of this study is to determine the influence of autonomy and authority, economic opportunity and challenge, security and work load, avoid responsibility, self realization and participation, social environment and career, and perceived confidence and contextual factors that include academic support, social support and support as well as the environment of gender factors on the intention of students to become entrepreneurs in student at School of Economic Pasundan Bandung, Indonesia. Therefore, this study may be useful in developing or challenging the scientific theories, and can be used as a barometer in the development of entrepreneurial intention of students at the college.

\section{Literature Review}

\subsection{Entrepreneurship}

Entrepreneurship is the result of a disciplined and systematic implementation process of creativity and innovation in meeting the needs and opportunities in the market (Zimmerer, 1996). The results of empirical research found the contribution of entrepreneurs in a country's economic development by preparing students to become entrepreneurs (Fox et al,. 2009). Reaching into entrepreneurial success can not be separated from the inherent characteristics, such as the characteristics, values, creative thinking, entrepreneurial attitude and personality. Characteristics of the entrepreneurs, according to Meredith (1996) include: (1) confident, (2) 
task and results oriented, (3) willing to take risks and challenge, (4) having strong leadership, (5) originality, and (6) having orientation towards the future. In addition, the values and behavior of entrepreneurs according Kuriloff \& Mempil (1993) are namely (1) having commitment to complete the task until the end, (2) taking moderate risk, do not do speculate on except by calculation, (3) seeing opportunities, taking advantage of opportunities as good as possible, (4) objective, performing real observations to obtain clarity, (5) feedback, analyzing performance data to guide the activities of the time, (6) optimistic, showing great confidence even though the situation is severe, (7) seeing money as a resource, not as a final destination, (8) proactive management, managing by planning for the future.

\subsection{Entrepreneur Intention}

Personality traits, or so-called as pscycological characteristics emphasized by individuals in deciding the type of work, are determined by the characteristics of their personality (Kolveried, 1996). Therefore, individual behavior can be measured with individual attitude approach in determining the type of work in the future. With known personal aspects and the process of opening a new business, it will be identifed which aspects are dominant in shaping aperson in determining his/her choice as an entrepreneur (Naffziger et al., 1994). In light of the above theory, it is necessary to know the attitudes of individuals to become entrepreneurs. Theory of Planned Behavior (Ajzen, 1985, 1987) is a theory that explains the effect of individual attitudes to become entrepreneurs and this includes (1) autonomy and authority, (2) economic opportunity and challenge, (3) security and work load, (4) avoid responsibility, (5) self-realization and participation, (6) social environment and career, (7) perceived confidence. In addition,the contextual factors include; (1) academic support, (2) social support, and (3) environment support.

\subsection{Hypotheses}

Based on the literature review and previous studies, the hypotheses of this study are as follows.

Hypothesis 1. Attitudes factor are more likely to have positive influence to become entrepreneurs.

Hypothesis 2. Contextual factor are more likely to have positive influence to become entrepreneurs.

Hypothesis 3. Gender factor are more likely to have positive influence to become entrepreneurs.

\section{Research Methodology}

This study used an exploratory method, which is to create a picture of a situation or phenomenon intended to causal-predictive analysis. This method was chosen due to the fairly large population, limited available time and cost, as well asthe sampling of the population studied. In addition, the survey method can also be doneon the assessment to give comparison of the results to draw conclusions. The sampling technique was by using accidental sampling of students at School of Economic Pasundan Bandung, Indonesia. Determination of the 
sample was based on several criteria, namely; 1) Active students 2) Be willing to fill out questionnaires distributed by the researcher, and 3) Minimum sample of $10 \%$ of the total population. Based on the primary data, it was obtained that the population is as many as 2,763 students from all courses in School of Economic Pasundan comprising Graduate Program, Undergraduate Program and Diploma Program. Of 300 questionnaires distributed, only 288 questionnaires were returned and there were 19 questionnaires incomplete, so that the number of respondents was as many as 269. Methods of data collection were by distributing questionnaires directly to the respondents who fit the criteria, establishing sample and observations, made directly on the object of research.

\subsection{Data Analysis}

This analysis was used to describe data related to attitude factors, contextual factors and gender factors on the intention of students to become entrepreneurs. As for the data processing, it was done with the help of Smart PLS 3.0 software and Microsoft Exel for Windows 2007. Operational variables in this study include attitude aspects and contextual factors. The attitude factors include: autonomy and authority (X1), economic opportunity and challenge (X2), security and work load (X3), avoid responsibility (X4), self-realization and participation (X5), social environment and career (X6), perceived confidence (X7) and entrepreneurial intention (Y). Meanwhile, contextual factors include: academic support (X1), social support (X2) and environment support (X3). The research instrument was using a 5-scale Likert technique (Summated Rating Scale), where any statement that was written could be agreed upon as a favorable or unfavorable statement, and the subject responded to each item of statement by using a level (intensity), for 'always' to 'never' on the statements provided, and then the scores were summed.

Structural Equation Modeling (SEM), component-based Partial Least Squares (PLS) were used as data analysis techniques. Those were chosen to develop a theory for prediction purposes in connection with the attitude factors and contextual factors that influence entrepreneurial intention of students at School of Economic Pasundan Bandung, Indonesia. A measurement model of Partial Least Squares (PLS) is based on measurement predictions that have a non-parametric nature through convergent validity, namely where the individual reflective size is correlated with the loading value of $>0,50$ (Chin, 1988) and the disciriminant validity value is measured by comparing the value of the square root of average variance extracted (AVE) of each construct and the correlation between the constructs in the model; if the value of AVE is greater than the value of the correlation between the constructs of the model, it is said to have a good disciriminant validity (Fornell\&Larcker, 1981). Moreover, it can also use the criteria of Cronbach's Alpha with a value > 0.6 (Nunnaly, 1996). Furthermore, the structural models were evaluated using the R-squares for the dependent construct, Stone-Geiser Q-square test for predictive relevance test and t test, and the significance of the parameters of structural lines. Testing the influence of gender on attitudes can be conducted by using a factor analysis approach which is multigroup, by identifying the path coefficients of each subsample and then they are compared and tested using pair-wise tests (Chin, 1999). 


\section{Al Macrothink}

International Journal of Human Resource Studies

ISSN 2162-3058

2015, Vol. 5, No. 3

\subsection{Validity and Reliability Test}

Data analysis was performed by entering all the data of respondents and testing the convergent validity, disciriminant validity, and significance tests. The results showed there are some indicators that do not meet the loading construct value of $>0.5$, so that some indicators are not included. For testing the attitude factors towards entrepreneurship intention, some indicators that do not meet the criteria are indicators auto1, auto2,eco1, eco5, soc2 and sec3. Therefore, of 36 indicators, 6 indicators do not meet criteria of validity and reliability. As for the contextual factors, two indicators that do not qualify are acad4 and env1, so that only 13 indicators that meet the criteria for Partial Least Squares (PLS) testing model.

Based on the results of the calculation attitudes and contectual factors towards entrepreneurial intention magnitude of the value obtained disciriminant validity based on Fornell - Larcker is as follows ;

Table 1 Disciriminant validity for attitude factor

\begin{tabular}{|l|l|l|l|l|l|l|l|l|}
\hline & Autonomy & Economic & Entre & Perceived & Respons & Security & Self_rea & Social \\
\hline Autonomy \& Authority & 0.698 & & & & & & \\
\hline Economic Opportunity & 0.514 & 0.735 & & & & & & \\
\hline Entrepreneur Intention & 0.241 & 0.189 & 0.830 & & & & & \\
\hline Perceived Confidence & 0.345 & 0.336 & 0.548 & 0.843 & & & \\
\hline Avoid Responsibility & 0.083 & -0.074 & -0.140 & -0.049 & 0.820 & & & \\
\hline Security \& Work load & 0.259 & 0.359 & 0.203 & 0.225 & 0.260 & 0.726 & & \\
\hline Self Realization & 0.399 & 0.599 & 0.365 & 0.500 & -0.134 & 0.298 & 0.759 & \\
\hline Social Environment & 0.413 & 0.552 & 0.300 & 0.481 & -0.064 & 0.370 & 0.611 & 0.782 \\
\hline
\end{tabular}


Table 2 Disciriminant validity for contextual factor

\begin{tabular}{|l|l|l|l|l|}
\hline & Academic & Entre & Environment & Social \\
\hline Academic Support & 0.712 & & & \\
\hline Entrepreneur Intention & 0.397 & 0.830 & & \\
\hline Environment Support & -0.007 & -0.076 & 0.800 & \\
\hline Social Support & 0.463 & 0.479 & -0.088 & 0.921 \\
\hline
\end{tabular}

And the results of the calculation factors disciriminant attitudes towards entrepreneurial intention validity based on the value Cronbachs Alpha and composite reliability and average variance extracted are as follows ;

Table 3 Cronbachs Alpha, Composite Reliability and Average Variance Extracted for attitudes factor

\begin{tabular}{|l|l|l|l|}
\hline & Cronbachs Alpha & AVE & $\begin{array}{l}\text { Composite } \\
\text { Reliability }\end{array}$ \\
\hline Autonomy \& Authority & 0.656 & 0.488 & 0.789 \\
\hline Economic Opportunity & 0.789 & 0.540 & 0.854 \\
\hline Entrepreneur Intention & 0.773 & 0.688 & 0.869 \\
\hline Perceived Confidence & 0.864 & 0.710 & 0.907 \\
\hline Avoid Responsibility & 0.757 & 0.672 & 0.860 \\
\hline Security \& Work load & 0.699 & 0.528 & 0.816 \\
\hline Self Realization & 0.751 & 0.576 & 0.844 \\
\hline Social Environment & 0.674 & 0.611 & 0.824 \\
\hline
\end{tabular}

And the calculation results of the contextual factors of entrepreneurial intention disciriminant validity based on the value Cronbachs Alpha and composite reliability and average variance extracted are as follows ; 


\section{Macrothink}

International Journal of Human Resource Studies ISSN 2162-3058 2015, Vol. 5, No. 3

Table 4 Cronbachs Alpha, Composite Reliability and Average Variance Extracted for contextual factor

\begin{tabular}{|l|l|l|l|}
\hline & Cronbachs Alpha & AVE & Composite Reliability \\
\hline Academic Support & 0.687 & 0.507 & 0.804 \\
\hline Entrepreneur Intention & 0.773 & 0.688 & 0.869 \\
\hline Environment Support & 0.758 & 0.640 & 0.841 \\
\hline Social Support & 0.911 & 0.848 & 0.943 \\
\hline
\end{tabular}

The calculations show that all the factors attitude has a value above 0.6 for Cronbachs alpha and composite reliability $>0.7$ while the average variance extracted one factor, namely the attitude of autonomy has a value below 0.5. Similarly, only the contextual factors which Cronbachs alpha values $>0.6$ and composite reliability $>0.7$ while the average variance extracted has a value above 0.5

\subsection{Hypotheses testing}

The results of path analysis and significance test calculation factor attitudes towards entrepreneurial intention is as follows;

Table 5 Path Coefficients for attitudes factor and Hypotheses testing

\begin{tabular}{|l|l|l|l|l|l|l|}
\hline & $\begin{array}{l}\text { Origina } \\
\text { Sample } \\
(\mathrm{O})\end{array}$ & $\begin{array}{l}\text { Seample } \\
\text { Me })\end{array}$ & $\begin{array}{l}\text { Standar } \\
\text { d Error } \\
(\text { STER } \\
\text { R })\end{array}$ & $\begin{array}{l}\text { T } \\
\text { Statistics } \\
(\mid \mathrm{O} / \text { STE } \\
\text { RR } \mid)\end{array}$ & P Values & $\begin{array}{l}\text { Cut Value } \\
5 \%\end{array}$ \\
\hline $\begin{array}{l}\text { Autonom } \\
\text {-> Entre }\end{array}$ & 0.084 & 0.081 & 0.060 & 1.382 & 0.168 & Not Significant \\
\hline $\begin{array}{l}\text { Economic } \\
->\text { Entre }\end{array}$ & -0.136 & -0.115 & 0.067 & 2.028 & 0.043 & Significant \\
\hline $\begin{array}{l}\text { Perceived } \\
->\text { Entre }\end{array}$ & 0.474 & 0.473 & 0.061 & 7.790 & 0.000 & Significant \\
\hline $\begin{array}{l}\text { Response } \\
->\text { Entre }\end{array}$ & -0.153 & -0.155 & 0.065 & 2.362 & 0.019 & Significant \\
\hline Security & 0.134 & 0.139 & 0.058 & 2.319 & 0.021 & Significant \\
\hline
\end{tabular}




\begin{tabular}{|l|l|l|l|l|l|l|}
\hline$\rightarrow$ Entre & & & & & & \\
\hline $\begin{array}{l}\text { Self_rea } \\
->\text { Entre }\end{array}$ & 0.134 & 0.129 & 0.072 & 1.851 & 0.065 & Not Significant \\
\hline $\begin{array}{l}\text { Social -> } \\
\text { Entre }\end{array}$ & -0.029 & -0.029 & 0.069 & 0.425 & 0.671 & Not Significant \\
\hline
\end{tabular}

$\mathrm{T}$ test results with the 0.05 level indicates that the variable economic opportunity and challenge, perceived confidence, avoid responsibility, and security and significant work load while the factor autonomy, self- realization and social environment does not significantly influence the entrepreneurial intention.

While the significance test calculation of the entrepreneurial intention contextual factors are as follows;

Table 6 Path Coefficients for contextual factor and Hypotheses testing

\begin{tabular}{|l|l|l|l|l|l|l|}
\hline & $\begin{array}{l}\text { Origina } \\
1 \\
\text { Sample } \\
(\mathrm{O})\end{array}$ & $\begin{array}{l}\text { Sample } \\
\text { Mean }\end{array}$ & $\begin{array}{l}\text { Standard } \\
\text { Error } \\
(\text { STERR })\end{array}$ & $\begin{array}{l}\text { T } \\
\text { Statistics } \\
(\mid \mathrm{O} / \text { STER } \\
\mathrm{R} \mid)\end{array}$ & P Values & $\begin{array}{l}\text { Cut Value } \\
5 \%\end{array}$ \\
\hline $\begin{array}{l}\text { Academic }-> \\
\text { Entre }\end{array}$ & 0.224 & 0.232 & 0.060 & 3.734 & 0.000 & Significant \\
\hline $\begin{array}{l}\text { Environment } \\
->\text { Entre }\end{array}$ & -0.042 & -0.045 & 0.080 & 0.521 & 0.603 & $\begin{array}{l}\text { Not } \\
\text { Significant }\end{array}$ \\
\hline $\begin{array}{l}\text { Social } \\
\text { Entre }\end{array}$ & 0.372 & 0.374 & 0.057 & 6.478 & 0.000 & Significant \\
\hline
\end{tabular}

$\mathrm{T}$ test results with the 0.05 level indicates that the variable academic support, and social support have a significant effect while environment factors do not support a significant effect on entrepreneurial intention.

The value of $\mathrm{R}$ squares adjusted for 0.323 , or $32.3 \%$ for the calculation of attitudes towards entrepreneurial intention factor as shown in the table below; 


\section{Ml Macrothink}

International Journal of Human Resource Studies

ISSN 2162-3058 2015, Vol. 5, No. 3

Table $7 \mathrm{R}$ squares adjusted attitudes factor and Hypotheses testing

\begin{tabular}{|l|l|l|l|l|l|l|}
\hline & $\begin{array}{l}\text { Original } \\
\text { Sample } \\
(\mathrm{O})\end{array}$ & $\begin{array}{l}\text { Sample } \\
\text { Mean }(\mathrm{M})\end{array}$ & $\begin{array}{l}\text { Standard Error } \\
(\text { STERR })\end{array}$ & $\begin{array}{l}\mathrm{T} \text { Statistics } \\
(\mid \text { O/STERR })\end{array}$ & $\begin{array}{l}\mathrm{P} \\
\text { Values }\end{array}$ & $\begin{array}{l}\text { Cut } \\
\text { Value } \\
5 \%\end{array}$ \\
\hline $\begin{array}{l}\text { Entrepren } \\
\text { eur }\end{array}$ & 0.323 & 0.349 & 0.053 & 6.083 & 0.000 & $\begin{array}{l}\text { Signific } \\
\text { ant }\end{array}$ \\
\hline
\end{tabular}

It can be concluded that the factors influence attitudes towards entrepreneurial intention for 03.23 , or $32.3 \%$ above the 6083 value $\mathrm{T} t$ table with 0.05 significant level.

And $\mathrm{R}$ squares adjusted for 0.323 , or $32.3 \%$ for the calculation of the entrepreneurial intention contextual factors as seen in the table below;

Table 8 R squares adjusted contextual factor and Hypotheses testing

\begin{tabular}{|l|l|l|l|l|l|l|}
\hline & $\begin{array}{l}\text { Origin } \\
\text { al } \\
\text { Sampl } \\
\text { e (O) }\end{array}$ & $\begin{array}{l}\text { Sample } \\
\text { Mean }\end{array}$ & $\begin{array}{l}\text { Standard } \\
\text { Error } \\
(\text { STERR })\end{array}$ & $\begin{array}{l}\text { T Statistics } \\
(\mid \text { O/STERR })\end{array}$ & P Values & Cut Value \\
\hline $\begin{array}{l}\text { Entrepr } \\
\text { eneur }\end{array}$ & 0.262 & 0.284 & 0.055 & 4.722 & 0.000 & Significant \\
\hline
\end{tabular}

The above table shows that contextual factors influence the entrepreneurial intention for 0.262 , or $26.2 \%$ with $\mathrm{T}$ values above $4,722 \mathrm{t}$ table with 0.05 significant level.

Testing the influence of gender on attitudes conducted by using a factor analysis approach multigroup and the results of the calculation are as follows;

Table 9 Coefficients gender factor for attitudes

\begin{tabular}{|l|r|r|r|r|r|}
\hline & Original Sample (O) & Sample Mean (M) & Standard Error (STERR) & T Statistics (|O/STERR|) & P Values \\
\hline Male -> EI & 0.628 & 0.663 & 0.047 & 13.419 & 0.000 \\
Female->EI & 0.448 & 0.498 & 0.055 & 8.155 & 0.000 \\
\hline
\end{tabular}

$$
\begin{aligned}
& t=\frac{\text { Pathsample1-Pathsample2 }}{\sqrt{\text { se2sample1+se2 sample } 2}} \\
& t=\frac{0.628-0.448}{\sqrt{(0.047) 2+(0.055) 2}}=\frac{0.18}{0.0723}=2.488
\end{aligned}
$$




\section{Macrothink}

International Journal of Human Resource Studies

ISSN 2162-3058 2015, Vol. 5, No. 3

$\mathrm{T}$ value amounted to 2,488 at 0.05 significant because the value of $t$ table above 1.96 , so it can be concluded that the type of sex through factors influence attitudes towards entrepreneurial intention. These results support the research Kristiansen \& Indarti (2004) which states that the gender factor significantly influence entrepreneurial intention.

While the test results to influence the sex of the entrepreneur intention contextual factors are as follows;

Table 10 Coefficients gender factor for contextual

\begin{tabular}{|l|r|r|r|r|r|}
\hline & Original Sample (O) & Sample Mean (M) & Standard Error (STERR) & T Statistics (|O/STERR|) & P Values \\
\hline & & & & & \\
Male -> EI & 0.597 & 0.623 & 0.070 & 8.506 & 0.000 \\
Female->EI & 0.491 & 0.516 & 0.055 & 8.860 & 0.000 \\
\hline
\end{tabular}

using the same formula as the following result;

$t=\frac{0.597-0.491}{\sqrt{(0.070) 2+(0.055) 2}}=\frac{0.1055}{0.08938}=1.180$

$\mathrm{T}$ value for 1180 is not significant at 0.05 because under the table t value is 1.96 , so it can be concluded that gender has no effect through contextual factor against entrepreneur intention. These results support the research Suharti and Sirine (2011) which states that gender did not significantly influence the entrepreneurial intention.

\section{Results}

\subsection{Characteristic of Respondent}

Based on the results of questionnaires, the data showed 269 respondents, consisting of students from four courses, in which respondents from Graduate program areas many as 37 people or $14 \%$ of the total population, with the number of male respondents is 16 people and 21 for female respondents. Undegraduate rrespondents from Accounting program areas many as 89 people or $33 \%$ of the total population, with the composition of 38 formen and 51 for women. In addition to Accounting program, there are respondents from Management program as many as 127 people or $47 \%$ of the total population with the composition of 54 male respondents and 73 female respondents. Diploma respondents majoring Accounting are as many as 7 people or $6 \%$ of the total population, with 7 male and 9 female respondents.

\subsection{Factors Influencing Attitudes Toward Entrepreneur Intention}

Based on the data processing by using software Smart PLS fit model is obtained as follows; 


\section{Macrothink}

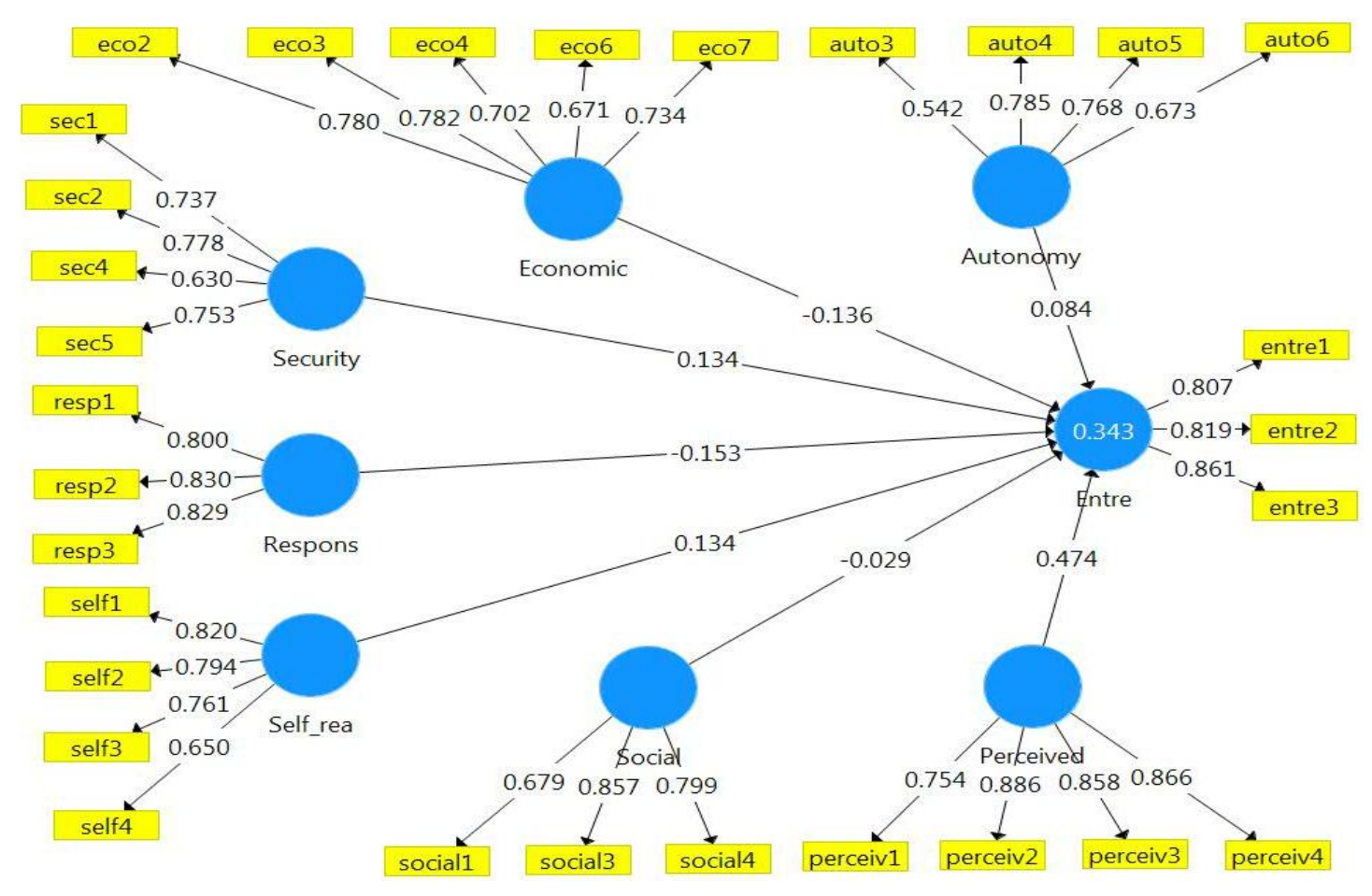

Figure 1 Fit model attitudes factor

From the model above which shows the results of the research, it can be concluded that;

(1) Autonomy and authority factorhasthe result of 0.084 or $8.4 \%$ with thet value of 1,382 . The result oft value is smaller than the significance level which is $5 \%$, so the attitude factor of autonomy and authority has no significant effect on the intention of students to become entrepreneurs. The result is consistent with research by Gurbuz and Aykol (2008) that showed autonomy and authority factors had no significant effect on the intention of students to become entrepreneurs. This indicates that the students are not influenced by the freedom and autonomy in determining what type of job they will have in the future.

(2) economic opportunity and challenge factor has a result of $-0.136 \mathrm{t}$ value, equal to the value of 2,028 . The result oft value is greater than the significance level of $5 \%$, so the attitude factor of opportunity and economic challenge significantly influences the intention of students to be entrepreneurs. The result indicatesthere is a negative influence of economic opportunity and challenge factor on the intention of students to become entrepreneurs. In other words, it can be said that the greater influence of economic opportunity and challenge faced by students will decrease their intention to become entrepreneurs. The result is contrast with research by Amos and Alex (2014) that the factor of economic opportunity and challenge positively influencedthe intention of students to become entrepreneurs.

(3) security and work load factorhas the resultof0.134 with t value of 2,319. The result of the $t$ value is greater than the significance level of $5 \%$, so the factor of security posture and work load significantly influences the intention of students to become entrepreneurs. This result I 
sconsistent with research by Gurbuz and Aykol (2008) that mentions the security and work load factors significantly influenced the intention of students to become entrepreneurs. This can be interpreted that students do not distinguish between the type of work that is too demanding workloads and reliability of their future careers.

(4) avoid responsibility factor has obtained the result of -0.153 , with the $t$ value, equal to 2.362. The result oft value is greater than the significance level of $5 \%$, so the responsibility factor significantly influences the intention of students to become entrepreneurs. The measurementresultissignificant but hasa negative impact on the intention of students to become entrepreneurs, thus it can be interpreted that the students donot want a big responsibility in choosing the type of work.

(5) self-realization and participation factor has the result of 0.134 with $t$ value equal to 1.851 . The result of $t$ value is smaller than the significance level of $5 \%$, so the attitude factor of self realization and participation does not significantly influence the intention of students to become entrepreneurs. This finding differs from the finding of the previous study by Gurbuz and Aykol (2008) which showed that self-realization and participation significantly influenced the intention of students to become entrepreneurs. This may imply that the students' level of initiative against creativity in utilizing resources is still low.

(6) social environment and career factor has resulted in $-0.029 \mathrm{~T}$ value, which equals to the value of 0.425 . The result of $t$ value is smaller than the significance level of $5 \%$, so the attitude factor of social and career environment has no significant effect on students' intention to become entrepreneurs. This result is supported by research of Suharti and Sirine (2011) which showed that social and career environment did not significantly influence the intention of students to become entrepreneurs. It can be said that the students are still less likely to engage in activities related to the field of organizational connection with the provision to be sociality.

(7) perceived confidence has a significance result by 0.474 or $47.4 \%$ to the t value as 7.790 . The result of thet value is greater than the significance level of $5 \%$, so the attitude factor of perceived confidence significantly influences the intention of students to become entrepreneurs. The result is consistent with research by Amos and Alex (2014) that showed the perceived confidence factor significantly influenced the intention of students to become entrepreneurs. This may imply that students have the strong assurance in themselves in starting a business in connection with the knowledge, skills and abilities.

Of the seven attitude factors, there are only four significant factors, namely variables of opportunity and economic challenge, perceived confidence, avoid responsibility, and security and work load, whereas the other variables do not significantly influence the intention of students to become entrepreneurs. However, the overall test results produce an adjusted R squares of 0.323 or $32.3 \%$ to $\mathrm{T}$ value, which equals to 6.083 . This finding indicates that the $\mathrm{T}$ value is greater than $5 \%$ significance level so it can be concluded that the attitude factors significantly influence the students' intention to become entrepreneurs. The influence of attitude factors is $32.3 \%$, while the rest is determined by other factors not included in this study. Thus it can be said that the results of this study support previous research by Gurbuz 


\section{Macrothink}

International Journal of Human Resource Studies

ISSN 2162-3058 2015, Vol. 5, No. 3

and Aykol (2008), Suharti and Sirine (2011), Sidharta and Sidh (2013) and Amos and Alex (2014) which reveal that the attitude factors significantly influence student's intention to be entrepreneurs.

\subsection{The influence of contextual factors on Intention to become Entrepreneurs}

Model fit for contextual factors that include academic support, social support and support environment for entrepreneurs intention is as follows;

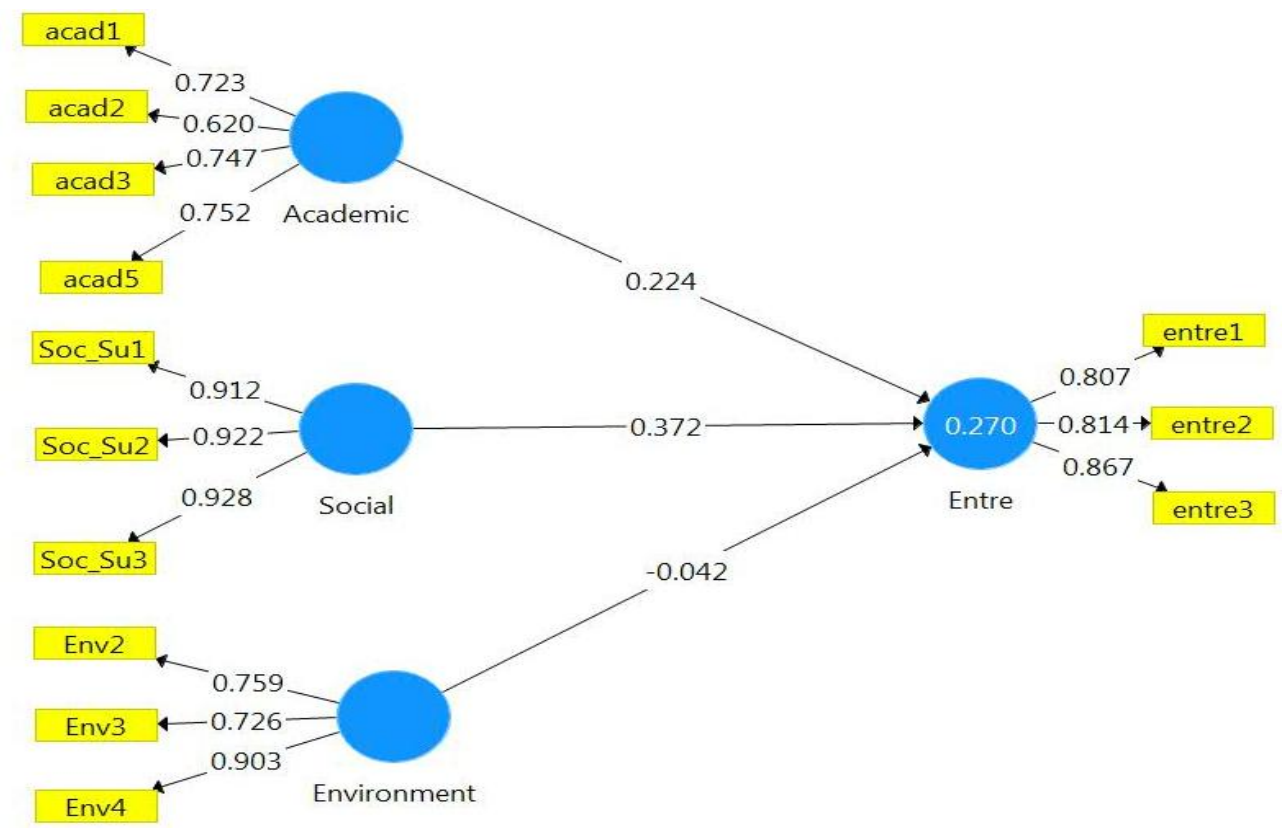

Figure 2 Fit model contextual factor

The picture above shows the results of research on the contextual factors that include academic support, social support and environment support for entrepreneurial intention, and it can be concluded that;

(1) academic support has a significant result by 0.224 or $22.4 \%$ to the $T$ value as 3,734 . The result oft value is greater than the significance level of 5\%, so the academic support as the contextual factor significantly influences the intention of students to become entrepreneurs. The results are consistent with the research by Amos and Alex (2014) which showed that the factor of academic support significantly influenced the intention of students to become entrepreneurs. It can be said that academic support gives an effect to the students in improving the intention to become entrepreneurs by giving them the freedom to cultivate their creative ideas.

(2) social supporthas a result of 0.372 or $37.2 \%$ with the $t$ value equal to 6.478 . The result of $t$ value is greater than the significance level of $5 \%$, so that contextual factor of social support significantly influences the intention of students to become entrepreneurs. The result of the 
study supports the previous research by Tong et al., (2011) who conducted research to Malaysia University students. The research found social support factor or subjective norm significantly influenced the intention of students to become entrepreneurs. The impact of the social environment influences the motivation of students to become entrepreneurs in the form of support from family and close friends.

(3) environment support has a result of -0.042 with the $t$ value equal to 0.521 . The result of $t$ value is smaller than the significance level of $5 \%$, so the contextual factor of environment support does not have a significant effect on the intention of students to become entrepreneurs. This findingis supported by research of Gurbuz and Aykol (2008) and Suharti and Sirine (2011) which stated that the environment support did not havea significant effect on the intention of students to become entrepreneurs. This means students still consider that the business climate in Indonesia still lacks of support in establishing a condition conducive to their efforts.

Of three independent variables, there are only two significant factors, namely academic support variable and social support variable, while the environment support variable has no significant effect on the intention of students to become entrepreneurs. Nevertheless, the overall test results produced an adjusted $\mathrm{R}$ squares of 0.262 or $26.2 \%$ to the $\mathrm{T}$ value equal to 2.625. This result indicates that the $\mathrm{t}$ value greater than $5 \%$ significance level means contextual factors significantly influence the intention of students to become entrepreneurs. The influence of contextual factors is at $26.2 \%$, while the rest is determined by other factors not included in this study. It can be said that previous research by Gurbuz and Aykol (2008), Suharti and Sirine (2011) and Amos and Alex (2014) which states that contextual factors significantly influence the intention of students to become entrepreneurs are supported based on these results.

\section{Conclusion, Recommendation and Limitation}

This study contributes to the theoretical development of Management Science, particularly entrepreneurial intention and entrepreneurship, considering the resources the college. Based on the results of this study, it is concluded that the attitude factors and contextual factors significantly influence the intention of students at School of Economic Pasundan Bandung Indonesia to become entrepreneurs. This may imply that the attitude factors of the students to become entrepreneurs are adequate where the confidence factor and perceived social support are strong enough, as those elements play a major role in shaping the students to become entrepreneurs. There is a need to increase optimal to avoid responsibility factors and academic support in order to improve its intention to become entrepreneurs as a reliable contribution in the creation of field of work. Increased students' intention to become entrepreneur in School of Economic Pasundan Bandung Indonesia can be realized by improving the skills related to self-confidence and autonomy in determining the choice of employment after graduation.

In this research, there are some limitations regarding the variables. Further research on the entrepreneurial intention is expected to include some variables, which can affect entrepreneurial intention on students, such as motivation, learning, and government support 
into a research model that can yield more comprehensive research findings.

\section{References}

Ajzen, I. (1985). From intentions to actions: A theory of planned behavior. In J. Kuhl \& J. Beckmann (Eds), Action-control: From cognition to behavior (pp. 11-39). Heldelberg: Springer.

Ajzen, I. (1987). Attitudes, traits, and actions: Dispositional prediction of behavior in personality and social psychology. In L. Berkowitz (Ed), Advances in experimental social psychology (Vol. 20, pp. 1-63). New York: Academic Press.

Ajzen, I. (1991). The Theory of Planned Behavior. Organizational Behavior And Human Decision Prosses, 50, 179-211.

Bates, T. (1991). Self-employed Entry Across Industri Groups. Journal of Business Venturing, 10, 143-156.

Baum, R. (1994). The Relation of Trait, Competencies, Vision, Motivation, and Strategy to Venture Growth. Unpublished doctoral dissertation, University of Maryland.

Chin, W. W. (1998). The Partial Least Squares Approach for Structural Equation Modelling. In Marcoulides, G. A. (Ed). Modern Method for Business Research. Mahwah. NJ. Erlbaum.

Fornell, C., \& Larcker, D. (1981). Evaluating Structural Equation Models with Unobservable Variable and Measurement Error. Journal of Marketing Research, 18, 39-50.

Fox, J., Llopis, F., Toney, B., Prueet, M., \& Shimar, R. (2009). Explaining Entrepreneurial Intentioans of university studens: A cross-cultural study. International Journal of Entreprenuerial Behaviour, 15(6), 571-594.

Gibb, A. A. (1994). Do We Really Teach (Approach) Small Business the Way We Should?. Journal of Small Business and Entrepreneurship, 11(2), 4-27.

Gorman, G., Hanlon, D. \& King, W. (1997). Some Research Perspective on Entrepreneurship Education, Enterprise Education and Education for Small Business Management: A Ten-Year Literature Review. International Small Business Journal, 15(3), 56-77.

Gurbuz, G., \& Aykol, S. 2008. Entrepreneurial Intentions of Young Educated Public in Turkey. Journal of Global Strategic Management, 4(1), 47-56.

Kristiansen, S., \& Indarti, N. (2004). Entrepreneurial Intentions among Indoenesian and Norwegian Studens. Journal of Enterprising Culture, 12(1), 55-78.

Kuratko, D. F. 2005. The Emergence of Entrepreneurship Education: Development, Trens, and Challenges. Entrepreneurship Theory and Practice, 12(1), 577-597.

Kuriloff, A. H. \& Memphil, J. M. (1993). Starting and Managing the Small Business $3^{\text {rd }}$ ed. New York: McGraw Hill. 


\section{Macrothink}

International Journal of Human Resource Studies

ISSN 2162-3058 2015, Vol. 5, No. 3

Machmud, S., \& Sidharta, I. (2013). Model Study of Strategic Management Approach In SMEs Sector Improvement In Bandung. Jurnal Computech \& Bisnis, 7(1), 56-66.

Machmud, S., \& Sidharta, I. 2014. Business Models For SMEs In Bandung: Swot Analysis. Jurnal Ekonomi, Bisnis \& Entrepreneurship, 8(1), 51-61.

Meredith, G. G. (1996). Kewirausahaan: Teori dan Praktek. Jakarta: Pustaka Binaman Presindo.

Nazir, M. 2011. Metode Penelitian, Cetakan Ke Tujuh. Bogor: Penerbit Ghalia Indonesia.

Neffziger, D. W., Hornsby, J. S., \& Kuratko, D. F. (1999). A Proposed Research model of Entrepreneurial Motivation. Entrepreneurship Theory and Practice, 18(3), 29-42.

Sekaran, U.2000. Research Methods for Business: A Skill Building, Third Editio. Singapore: John Wiley and Sons.

Sidharta, I., \& Sidh, R. (2013). Analysis of Factors Forming Intentions Student Attitudes Become Technopreneur. Jurnal Computech \& Bisnis, 7(2), 56-66.

Sidharta, I., \& Lusyana, D. (2014). Competency-Based Analysis Concept Determinants of Knowledge, Skill, and Ability (KSA) In Center of Clothing Suci, Bandung. Jurnal Computech \& Bisnis, 8(1), 49.

Suharti, L., \& Sirine, H. (2011). Faktor-Faktor yang Berpengaruh Terhadap Niat Kewirausahaan (Entrepreneurial Intention), (Studi Terhadap Mahasiswa Universitas Kristen Satya Wacana, Salatiga). Jurnal Manajemen dan Kewirausahaan, 13(2), 124-134.

Tong, X. F., Tong, D. Y. K. F., \& Loy, L. G. (2011). Factors Influencing Entrepreneurial Intention Among University Student. International Journal of Sciences And Humanity Stuides, 3(1), 487-496.

Zimmerer, W. T., \& Scarborough, N. M. (1996). Entrepreneurship and the New Venture Formation. New Jersey: Prentice Hall International, inc.

The 1945 Constitution 